\title{
Impacts of trawling disturbance on the trophic structure of benthic invertebrate communities
}

\author{
Simon Jennings ${ }^{1, *}$, John K. Pinnegar ${ }^{2}$, Nicholas V. C. Polunin ${ }^{2}$, Karema J. Warr ${ }^{1}$ \\ ${ }^{1}$ Centre for Environment, Fisheries and Aquaculture Science, Lowestoft Laboratory, Lowestoft NR33 0HT, United Kingdom \\ ${ }^{2}$ Department of Marine Sciences and Coastal Management, The University, Newcastle upon Tyne NE1 7RU, United Kingdom
}

\begin{abstract}
Bottom trawling causes chronic and widespread disturbance to the seabed in shallow shelf seas and could lead to changes in the trophic structure and function of benthic communities, with important implications for the processing of primary production and the wider functioning of the marine ecosystem. We studied the effects of bottom trawling on the trophic structure of infaunal and epifaunal benthic communities in 2 regions (Silver Pit and Hills) of the central North Sea. Within each region, we quantified long-term (over $5 \mathrm{yr}$ ) differences in trawling disturbance at a series of sites (using sightings data from fishery protection flights), and related this to differences in the biomass and trophic structure of the benthic community. There were 27- and 10-fold differences in levels of beam trawl disturbance among the Silver Pit and Hills sites respectively, and we estimated that the

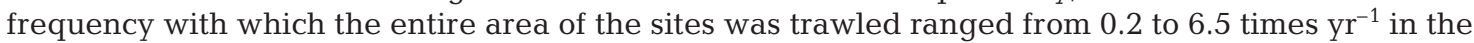
Silver Pit and 0.2 to 2.3 times $\mathrm{yr}^{-1}$ in the Hills. The impacts of fishing were most pronounced in the Silver Pit region, where the range of trawling disturbance was greater. Infaunal and epifaunal biomass decreased significantly with trawling disturbance. Within the infauna, there were highly significant decreases in the biomass of bivalves and spatangoids (burrowing sea-urchins) but no significant change in polychaetes. Relationships between trophic level (estimated using nitrogen stable isotope composition, $\delta^{15} \mathrm{~N}$ ) and body mass (as $\log _{2}$ size classes) were rarely significant, implying that the larger individuals in this community did not consistently prey on the smaller ones. For epifauna, the relationships were significant, but the slopes or intercepts of the fitted linear regressions were not significantly related to trawling disturbance. Moreover, mean $\delta^{15} \mathrm{~N}$ of the sampled infaunal and epifaunal communities were remarkably consistent across sites and not significantly related to trawling disturbance. Our results suggest that chronic trawling disturbance led to dramatic reductions in the biomass of infauna and epifauna, but these reductions were not reflected in changes to the mean trophic level of the community, or the relationships between the trophic levels of different sizes of epifauna. The trophic structure of intensively trawled benthic invertebrate communities may be a robust feature of this marine ecosystem, thus ensuring the efficient processing of production within those animals that have sufficiently high intrinsic rates of population increase to withstand the levels of mortality imposed by trawling.
\end{abstract}

KEY WORDS: North Sea $\cdot$ Fishing effects $\cdot$ Benthic infauna $\cdot$ Benthic epifauna $\cdot$ Trophic relationships $\cdot$ Stable isotopes $\cdot$ Community structure $\cdot$ Beam trawling $\cdot$ Food webs

\section{INTRODUCTION}

Many studies have described the impacts of bottom trawling on the structure of benthic communities (reviews: Dayton et al. 1995, Jennings \& Kaiser 1998, Lindeboom \& de Groot 1998, Hall 1999, Kaiser \& de Groot 2000). They have focused on changes in the relative abundance of different species in the benthic

*E-mail: s.jennings@cefas.co.uk community, but have not dealt directly with changes in the trophic structure or function of that community. We might expect trawling to have profound effects on the trophic structure and function of benthic communities, because certain functional groups, such as large filterfeeding bivalves, are more vulnerable to trawling disturbance than others (Lindeboom \& de Groot 1998).

A large proportion of the seabed in northeast Atlantic shelf seas is disturbed by bottom trawling (Rijnsdorp et al. 1996, Kaiser 1998, Greenstreet et al. 
1999, Jennings et al. 1999a), and small (10s of $\mathrm{km}^{2}$ ) intensively fished areas in the southern North Sea may be trawled 10 or more times each year (Rijnsdorp et al. 1998). If quantified levels of bottom trawling disturbance could be linked to quantifiable changes in the trophic structure of benthic communities, this would be a first step towards describing and mitigating any indirect effects of fishing on ecosystem function. To date, the best evidence for fishing effects on trophic structure comes from changes in the trophic level of global catches. Pauly et al. (1998) documented a decrease in the trophic level of catches as larger and more vulnerable species at the highest trophic levels were depleted and fishers 'fished down the food chain' in order to maintain yields. However, fishing has many impacts other than those on target species (Jennings \& Kaiser 1998, Hall 1999). Bottom trawls, for example, crush benthic invertebrates in the path of the net and lead to the mortality of invertebrates that are caught in the net and subsequently discarded because they have little or no commercial value (Jennings \& Kaiser 1998, Lindeboom \& de Groot 1998, Hall 1999, Kaiser \& de Groot 2000). The mortality suffered by larger benthic species is generally greater than that of smaller species (Gilkinson et al. 1998, Lindeboom \& de Groot 1998), and larger species, with lower intrinsic rates of natural increase (Brey 1999), are more likely to decline in abundance at a given rate of mortality. Since larger species are often those at higher trophic levels (because predators are usually larger than their prey; Cohen et al 1993), the reductions in abundance of larger species might be expected to reduce the mean trophic level of the community.

Short-term reductions in benthic biomass and shifts in community structure following trawling disturbance are well known from experimental studies (Bergman \& Hup 1992, Thrush et al. 1995, Currie \& Parry 1996, Kaiser \& Spencer 1996, Tuck et al. 1998, Bradshaw et al. 2000). The effects of trawling on infauna are more noticeable in areas where levels of natural disturbance are low than where they are high (Brylinsky et al. 1994, Kaiser \& Spencer 1996), because the community is already adapted to disturbance (Jennings \& Kaiser 1998). Recovery of the community following trawling also depends on levels of natural disturbance. At a site with strong tidal currents and mobile substratum, Kaiser \& Spencer (1996) showed that experimental trawling changed the community, but 6 mo later, there were no significant differences between trawled and untrawled sites (Kaiser et al. 1998). Similarly rapid recovery of fauna in a coarse sand was observed by Thrush et al. (1995) in New Zealand. In more stable areas, recovery is longer. Tuck et al. (1998) studied trawling effects in a previously untrawled muddy area, and changes were still apparent after 18 mo. Similarly, Collie et al. (1997) showed recovery from scallop dredging took at least 2 yr. Collie et al. (2000) synthesised recovery data from a variety of studies in a meta analysis. Their results suggested that the fauna of sandy seabeds often recovered in around $100 \mathrm{~d}$ and could tolerate 2 to 3 trawl passes a year. We must assume that measured rates of recovery for mobile species are largely due to immigration, since what is known of the life histories of benthic species (Brey 1999) suggests that population regeneration would not occur on this time scale. This means that the effects of repeated trawling over large areas, as occurs in real fisheries, may have collective effects that would not be detected by studies of recovery in small experimental areas.

Small-scale experimental studies provide a statistically powerful way of detecting trawling effects, but do not replicate the large-scale and long-term disturbance that occurs in real fisheries (Kaiser et al. 2000). Study of trawling effects at the scale of the fishery is especially important if we are to understand effects at the ecosystem scale. For example, there have been dramatic and long-term changes in the benthic fauna of the southern and central North Sea, and trawling could easily be implicated as a cause, because trawling effort has risen over the same period (Lindley et al. 1995, Heessen \& Daan 1996). In the southern North Sea, there has been a shift towards a community of higher biomass that is dominated by polychaetes rather than larger bivalves (Kröncke 1990, 1992, Kröncke et al. 1998). The reduction in bivalves has been attributed to the mortality caused by contact with trawls (Lindeboom \& de Groot 1998), while polychaetes could proliferate because they suffer lower mortality and have life histories that imply higher intrinsic rates of population increase (Brey 1999). Reductions in the abundance of larger burrowing urchins (spatangoids) are also an expected consequence of trawling disturbance, as these can suffer 10 to $50 \%$ mortality in the path of trawls (Lindeboom \& de Groot 1998). Intriguingly, the temporal changes in North Sea benthos (Kröncke 1990, 1992, Kröncke et al. 1998) during a period of increasing beam trawling effort (Jennings et al. 1999a), have mimicked those demonstrated in experimental studies, where bivalves became scarce and polychaetes proliferated (Tuck et al 1998). However, eutrophication and climatic effects are predicted to be responsible for much of the proliferation of polychaetes in the North Sea (Kröncke et al. 1998), and quantitative assessment of the relationship between trawling disturbance and polychaete abundance would help to resolve the relative roles of eutrophication, climate and disturbance.

A major impediment to the study of trawling disturbance of benthic communities is the paucity of data that quantify levels of trawling disturbance on appro- 
priate spatial and temporal scales; in addition, with few exceptions, trawling effects have not been examined across quantifiable gradients of disturbance (Collie et al. 1997, Thrush et al. 1998, Kaiser et al. 2000). In the North Sea, international trawling effort data are collated by ICES statistical rectangle (211 boxes of $0.5^{\circ}$ North-South and $1^{\circ}$ East-West). These are very large areas $\left(3720 \mathrm{~km}^{2}\right.$ at $\left.53^{\circ} \mathrm{N}\right)$ and trawling effort in the rectangles is very patchy (Rijnsdorp et al. 1998). Since benthic sampling can only be conducted on spatial scales several orders of magnitude below that of the rectangle, it is impossible to know if a sampling site has actually been disturbed by trawling. One alternative is to attempt to quantify trawling disturbance on much smaller scales using biological indicators. For example, rates of scarring in the shells of large bivalves such as Arctica islandica (Witbaard \& Klein 1994) and Glycimeris glycimeris (Kaiser et al. 2000), or the whelk Buccinum undatum (Mensink et al. 2000) reflect the frequency with which they are hit by bottom trawls. However, not all individuals recover when they are hit by trawls, and larger bivalves in the path of a beam trawl typically suffer mortality of $20 \%$ or more (Lindeboom \& de Groot 1998, Bergman \& van Santbrink 2000). As a result, species such as Arctica islandica have been extirpated in heavily trawled areas (Rumohr \& Krost 1991, Craeymeersch et al. 2000) and cannot be used to differentiate between higher levels of disturbance.

An alternative method for quantifying trawling disturbance on relatively small scales is to use records of vessels sighted by aircraft that patrol the fishing grounds around the United Kingdom. The crew on these aircraft record the description and location of all vessels they see fishing. Relative trawling disturbance can be estimated as the number of actively fishing trawlers sighted per unit of search effort per unit area. While the spatial resolution of fishery protection data is not quite as good as that collected from position loggers on trawlers or satellite tracking, the former has not been applied to all trawlers that prosecute the southern and central North Sea fisheries and the latter has only been applied since 1 January 2000.

We describe the trophic structure of benthic invertebrate communities by using stable isotopes of nitrogen as an index of trophic level. Studies of nitrogen stable isotope $\left({ }^{14} \mathrm{~N}\right.$ and $\left.{ }^{15} \mathrm{~N}\right)$ composition can provide indices of trophic level and thus provides a useful tool for investigating trophic relationships (Peterson et al. 1985, Owens 1987, Peterson \& Fry 1987, Fry \& Sherr 1989, Preston 1992). The $\delta^{15} \mathrm{~N}$ in the tissues of predators is typically $\sim 3 \%$ greater than their prey and thus ${ }^{15} \mathrm{~N}$ studies have been used to define the trophic levels of organisms in systems where feeding relationships are not known (Minawaga \& Wada 1984, Owens 1987 ,
Hobson \& Welch 1992, Fry \& Quinones 1994), although in reality, there is variation around the mean level of enrichment due to differences in $\mathrm{C}: \mathrm{N}$ ratios of the tissue and nutritional status (Adams \& Sterner 2000). Stable isotope analysis allows the estimation of trophic level for species such as small invertebrates, for which it would be impossible to quantify diet on a systematic basis (Minawaga \& Wada 1984, Owens 1987).

In the present study we compare benthic communities among sites subject to different levels of trawling disturbance in 2 regions of the North Sea. The fauna in these regions is dominated by free-living infauna and epifauna living in mobile sediment, typical benthic communities of North Sea beam trawl grounds (e.g. Künitzer et al. 1992). We focus on aggregate responses of the community to trawling rather than those of individual species. We attempt to link structural changes in the abundance of species groups to those in the trophic structure of the community. This is a fundamental step towards understanding the impacts of trawling disturbance on patterns of production and energy use in marine ecosystems. We focus on differences among sites that have been subject to different levels of trawling disturbance for at least 5 yr. We seek to address the following questions: (1) How does trawling disturbance affect the total biomass of infauna and epifauna? (2) Is there evidence for a shift in the infaunal community from one that is dominated by bivalves and spatangoids to one that is dominated by polychaetes? (3) Does trawling disturbance favour species from lower trophic levels and lead to a fall in the trophic level of the community? (4) Does trawling disturbance affect any size-based predator-prey relationships that are seen in the community?

\section{METHODS}

Study sites. The impact of trawling disturbance on the trophic structure of infaunal and epifaunal benthic communities was investigated in 2 series of sites subject to different levels of fishing disturbance in 2 regions of the North Sea (Fig. 1). The regions were chosen because a preliminary analysis showed that there were marked variations in trawling effort within each region, even though the depths, sediments and temperature regimes in each region were similar (Lee \& Ramster 1981, British Geological Survey unpubl. data, CEFAS unpubl. data). The first region was the Silver Pit, where the depth ranges from 60 to $80 \mathrm{~m}$ and the sediment is muddy sand (mean particle diameter in Silver Pit $=0.02$ to $0.09 \mathrm{~mm}$; British Geological Survey unpubl.). The second region was the Hills, where depths are 40 to $60 \mathrm{~m}$ and the sediment is sandy (mean particle diameters in Hills $=0.250$ to $0.350 \mathrm{~mm}$; 


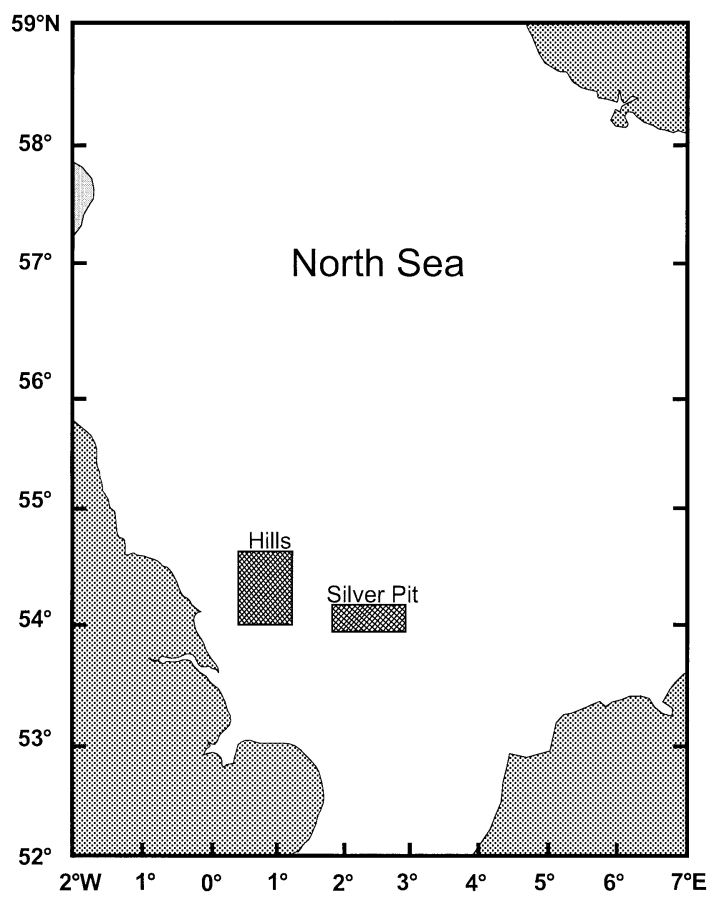

Fig. 1. The Hills and Silver Pit regions in the North Sea. The shaded boxes show the areas in which sampling sites were selected. The boundaries of the shaded boxes correspond to the boundaries of the boxes shown in Figs. $2 \& 3$. Note that $1^{\circ}$ of latitude is 60 nautical miles (approx. $111 \mathrm{~km}$ )

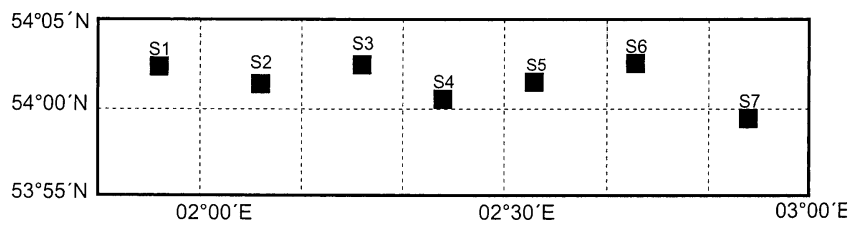

Fig. 2. The 7 study sites (S1-S7) in the Silver Pit region of the North Sea. Each study site is shown as a shaded square of $1 \mathrm{n}$ mile $^{2}$. The broken lines show the boundaries of the areas where trawling disturbance was assessed

British Geological Survey unpubl.). Preliminary study of the invertebrate communities in each region showed that free-living species accounted for most of the total biomass and numerical abundance of the epifaunal (Jennings et al. 1999b) and infaunal (S.J. et al. unpubl.) community. Seven sites subject to different levels of trawling disturbance were studied in the Silver Pit (Fig. 2), and 13 sites in the Hills (Fig. 3). Each site was designated as an area of $1 \mathrm{n}$ mile North-South $(1 \mathrm{n}$ mile $=1853 \mathrm{~m}$ ) by $1 \mathrm{n}$ mile East-West.

Estimation of trawling disturbance. The trawling disturbance at each site was determined from records of vessel sightings by fishery protection aircraft. These aircraft patrol the fishing grounds around the United

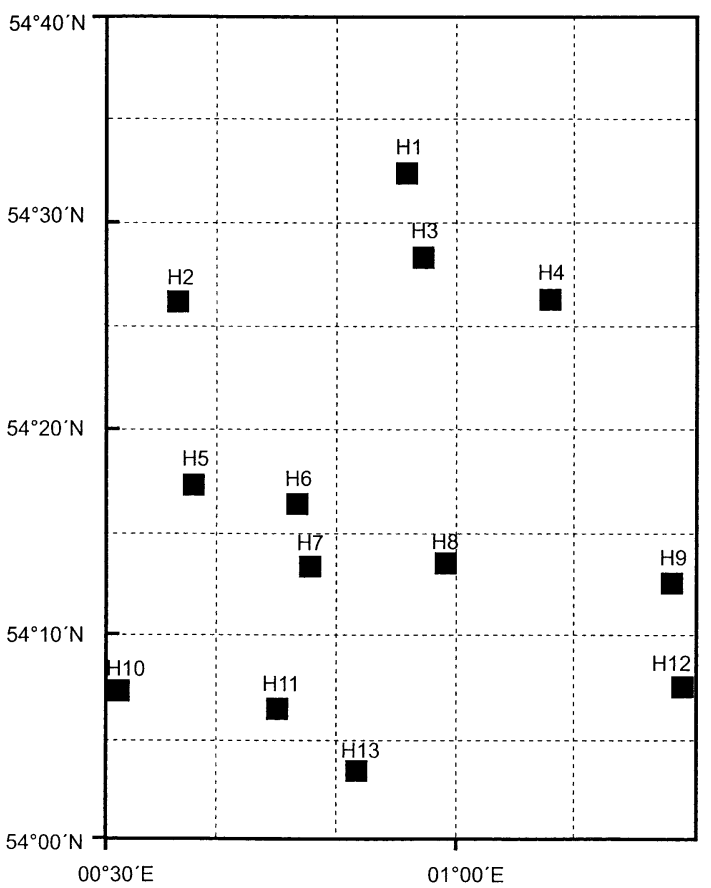

Fig. 3. The 13 study sites $(\mathrm{H} 1-\mathrm{H} 13)$ in the Hills region of the North Sea. Each study site is shown as a shaded square of $1 \mathrm{n}$ mile $^{2}$. The broken lines show the boundaries of the areas where trawling disturbance was assessed

Kingdom and record a description and location of all vessels that they observe fishing. In the southern and central North Sea, fishery protection flights visit most ICES (International Council for the Exploration of the Sea) sub-rectangles (there are 4 sub-rectangles per rectangle, each sub-rectangle is $0.5^{\circ}$ North-South by $0.5^{\circ}$ East-West) around 100 times $\mathrm{yr}^{-1}$. Relative trawling disturbance can be estimated as the number of trawlers sighted per unit of searching effort (SPUE) (Jennings et al. 2000).

The Silver Pit and Hills regions (Fig. 1) were divided into $5 \mathrm{n}$ mile $(9265 \mathrm{~m})$ (North-South) by $6 \mathrm{n}$ mile (11 $118 \mathrm{~m})$ (East-West) areas, working south from the northern limit of the maps in Figs. 2 \& 3. Within each area, the mean number of beam or otter trawls SPUE was calculated (effort was measured as the number of visits by a fishery protection aircraft). We used records of all sightings of actively fishing beam and otter trawlers in the Silver Pit and Hills regions from 1 January 1994 to 31 December 1998. In this period, aircraft visited sub-rectangles in the Silver Pit with a mean frequency of 103.7 to 153 visits $\mathrm{yr}^{-1}$, and sub-rectangles in the Hills with a mean frequency of 121.2 to 160.2 visits $\mathrm{yr}^{-1}$ (Jennings et al. 2000). Trawling effort in the $1 \mathrm{n}$ mile $^{2}\left(3.43 \mathrm{~km}^{2}\right)$ study sites within the $30 \mathrm{n} \mathrm{mile}$ $\left(103 \mathrm{~km}^{2}\right)$ area was taken as $1 / 30$ th of that in the $30 \mathrm{n}$ mile ${ }^{2}$ area. This was preferable to calculating SPUE in 
the $1 \mathrm{n}$ mile ${ }^{2}$ study sites, because the error associated with locating a vessel inside or outside such a small area is very large when modern beam trawlers fish at up to 7 knots $\left(13 \mathrm{~km} \mathrm{~h}^{-1}\right)$ and can travel $1 \mathrm{n}$ mile $(1853 \mathrm{~m})$ in less than $10 \mathrm{~min}$. For the quantitative analysis of differences in community and trophic structure among sites, we assumed that SPUE was directly and linearly proportional to trawling effort and trawling disturbance. We expressed the level of trawling disturbance as an index, where the lowest level of disturbance was given a value of 1 on a linear scale. Clearly, our approach assumes that trawling and aircraft search patterns within the areas are random. We recognise that this assumption will be violated and introduce some bias, but side-scan observations of trawl tracks within the Silver Pit study sites (where the sediment is sufficiently soft for trawl tracks to persist for a few days after trawling) suggest that track frequency and SPUE are correlated and that tracks cross the more heavily fished sites in many directions (S.J. unpubl. data). However, with existing data, we cannot quantify the bias that trawling and aircraft search patterns introduce.

Since the relative impacts of beam trawls on the benthic community are considerably greater than those of otter trawls (Lindeboom \& de Groot 1998, Bergman \& van Santbrink 2000), we related changes in trophic structure to differences in beam trawling effort. However, otter trawler SPUE data have been provided for comparative purposes. In all analyses we assume that the rate of SPUE is directly and linearly proportional to fishing effort and disturbance.

Sampling of benthic community. Epibenthic invertebrates were sampled with a $2 \mathrm{~m}$ beam trawl and infaunal invertebrates with an anchor dredge. The beam trawl was fitted with a chain mat and a $1 \mathrm{~mm}$ mesh liner and was fished from the stern gantry of the RV 'Corystes', using a warp length of 3 times the water depth. Three randomly located replicate tows were completed at each site. Each tow was 5 min in duration at a speed of $1 \mathrm{knot}\left(1.853 \mathrm{~km} \mathrm{~h}^{-1}\right)$. The $5 \min$ period was timed from the moment that the net contacted the seabed until the moment of hauling from the seabed. Operational constraints meant that the distance trawled had to be confirmed retrospectively, using Sextant software linked to the ship's differential global positioning system (DGPS). The design and operation of the $2 \mathrm{~m}$ beam trawl is described in detail by Jennings et al. (1999b). Three randomly located replicate tows of 1 min duration were also made with an anchor dredge (Kaiser et al. 2000). The sediment collected was emptied on the deck of the ship and a $0.2 \mathrm{~m}^{3}$ sub-sample removed. This was sieved through $1 \mathrm{~mm}$ square mesh, and all infaunal species retained by the mesh were removed for processing. All sampling was conducted from 29 October to 8 December
1999, and depth was measured at the location where each gear was first deployed.

We deliberately chose gears that sampled relatively large areas of seabed, even though the samples they take reflect relative rather than absolute abundance. Both gears sample on an appropriate scale for the study of fishing effects (over areas of $\mathrm{m}^{2}$ to $10 \mathrm{~s}$ of $\mathrm{m}^{2}$ ) and integrate small-scale patchiness of the benthic fauna. We assumed that the catchability of different species did not change from site to site, so bias in abundance estimates was consistent. Only free-living (species not anchored to shell, stone, rock or sand) epifaunal species were retained from the beam trawl samples, and free-living infauna from the anchor dredge samples. Epifauna were defined as those species that live on the seabed or burrow into it temporarily, while infauna were defined as those that live predominantly in the substrate.

All infauna from the replicate anchor dredge samples and epifauna from the replicate beam trawl samples were identified, individually weighed on heave compensated balances and assigned to $\log _{2}$ size classes. Hermit crabs (Paguridae) were weighed after removal from their shells, but animals that secreted their own shells were weighed with the shells intact. To obtain tissue samples for stable isotope analysis, animals from the same size class in each of the 3 replicate samples of (a) infauna and (b) epifauna from each site were combined and homogenised in an electric blender, usually with added water, to produce a thoroughly mixed suspension that poured smoothly. Approximately $7 \mathrm{ml}$ of this suspension was frozen to $-20^{\circ} \mathrm{C}$ in a glass vial. Shells were removed from all bivalves before blending.

Stable isotope analysis. The frozen samples of homogenised tissue were freeze dried, and the freeze dried material was crumbled or ground to a fine powder (particles $<60 \mu \mathrm{m}$ ). The ${ }^{15} \mathrm{~N}$ composition of the samples was determined using continuous flow isotope ratio mass spectrometry (CF-IRMS) (Preston \& Owens 1983, Preston 1992). Weighed samples of $1.0 \mathrm{mg}$ ground material were oxidised and the $\mathrm{N}_{2}$ passed to a single inlet dual collector mass spectrometer (Automated Nitrogen Carbon Analysis [ANCA] SL 20-20 system). This was a continuous flow system, so 2 samples of reference material (an internal standard-in this case homogenised cod Gadus morhua tissue with similar nitrogen content to the samples we analysed) were analysed after every 5 tissue samples in order to calibrate the system and compensate for drift with time (ANCA-SL Dual Isotope v3.4 software).

Ratios of ${ }^{15} \mathrm{~N}:{ }^{14} \mathrm{~N}$ were expressed relative to $\mathrm{N}_{2}$ in air for nitrogen and calculated as:

$$
\delta{ }^{15} \mathrm{~N}=\left({ }^{15} \mathrm{~N}:{ }^{14} \mathrm{~N}_{\text {sample }} /{ }^{15} \mathrm{~N}:{ }^{14} \mathrm{~N}_{\text {standard }}-1\right) \times 10^{3}
$$


The mean $\delta^{15} \mathrm{~N}$ for the infaunal or epifaunal community at each site was calculated as a weighted mean of $\delta^{15} \mathrm{~N}$ by size class. The SD for the repeated $\delta^{15} \mathrm{~N}$ measurements made with the reference material was $0.1 \%$. Two samples were excluded from the final analysis. First, an infaunal sample in the 8.1 to $16.0 \mathrm{~g}$ size class from Site S4 which contained only $0.202 \%$ N, below the recommended tolerance of the ANCA system and significantly below the mean nitrogen content $(9.3 \pm 2.75 \%)$ for other samples in this size class taken at Silver Pit. Second, an infaunal sample in the 1.1 to $2.0 \mathrm{~g}$ size class from Site H13 which contained only $0.435 \% \mathrm{~N}$, also below the recommended tolerance of the ANCA system and significantly below the mean nitrogen content $(9.8 \pm 1.61 \%)$ for other samples in this size class taken at the Hills sites. We do not know why the $\mathrm{N}$ content of these samples was so low.

\section{RESULTS}

All the study sites were trawled. There was a 27 -fold range in beam trawl SPUE among the Silver Pit sites and 10-fold among the Hills sites, and the most intensively trawled site in the Silver Pit was trawled almost 3 times more often than the most frequently trawled sites in the Hills (Table 1). Sites with high beam trawling disturbance were usually subject to high otter trawling disturbance too, and the ranking of sites within regions by total trawling disturbance and beam trawling disturbance was relatively similar. Mean depths at the Silver Pit sites ranged from 58.9 to $72.2 \mathrm{~m}$ and from 44.0 to 62.2 at the Hills sites (Table 1).

The total biomass (all references to biomass refer to biomass per sample) of infauna and epifauna decreased significantly with trawling disturbance in the Silver Pit (linear regression: infauna $\mathrm{r}^{2}=0.68, F_{1,5}=$ 10.78, $\mathrm{p}=0.022$; epifauna $\mathrm{r}^{2}=0.60, F_{1,5}=7.34, \mathrm{p}=$ 0.042 ; Fig. 4). The slope of the relationship between infaunal biomass and trawling disturbance $(b=0.0376)$ suggested that there would be an order of magnitude decrease in infaunal biomass when trawling disturbance was increased 27 -fold. For epifauna, the slope ( $b=0.0162)$ suggested an equivalent decrease when trawling disturbance increased 62-fold. Trends in total biomass of infauna and epifauna in relation to fishing disturbance were not significant at the Hills sites (infauna: $F_{1,11}=0.10 \mathrm{p}=0.761$; epifauna: $F_{1,11}=0.80$, $\mathrm{p}=0.389$; Fig. 4).

Analysis of the gross composition of the infaunal community at Silver Pit (Fig. 5) showed that there was a highly significant decrease in biomass of bivalves

Table 1. Mean sightings per unit searching effort (SPUE) of beam trawlers and otter trawlers by fishery protection flights in the Silver Pit and Hills areas of the North Sea. SPUE is assumed to be directly and linearly related to trawling effort and trawling disturbance. Rank 1 corresponds to the highest fishing effort. Apparent discrepancies in the additions of beam and otter trawl effort and calculations of indices are due to rounding. Depth is the mean of depths recorded on deployment of the three $2 \mathrm{~m}$ beam trawls and 3 anchor dredges at each site

\begin{tabular}{|c|c|c|c|c|c|}
\hline Site & $\begin{array}{l}\text { Beam trawl } \\
\text { effort } \\
\left(\text { SPUE } \times 10^{3}\right)\end{array}$ & $\begin{array}{l}\text { Otter trawl } \\
\text { effort } \\
\left(\text { SPUE } \times 10^{3}\right)\end{array}$ & $\begin{array}{c}\text { Total trawl } \\
\text { effort } \\
\text { (SPUE } \times 10^{3} \text { and rank) }\end{array}$ & $\begin{array}{l}\text { Index of relative beam } \\
\text { trawl disturbance } \\
\text { (index and rank) }\end{array}$ & $\begin{array}{c}\text { Depth }(\mathrm{m}) \\
(\text { mean } \pm \text { SEM) }\end{array}$ \\
\hline \multicolumn{6}{|c|}{ Silver Pit } \\
\hline S1 & 1.57 & 1.91 & 3.48 (6) & 5.12 (6) & $72.2 \pm 1.20$ \\
\hline $\mathrm{S} 2$ & 3.87 & 1.50 & 5.37 (5) & 12.53 & $69.0 \pm 1.56$ \\
\hline S3 & 6.86 & 1.22 & 8.08 (4) & 22.18 (2) & $66.6 \pm 0.67$ \\
\hline S4 & 6.08 & 3.98 & 10.06 & $19.65(4)$ & $64.9 \pm 0.70$ \\
\hline S5 & 9.51 & 9.09 & 18.60 & 30.82 (1) & $59.5 \pm 2.88$ \\
\hline S6 & 6.72 & 11.22 & 17.94 (2) & 21.82 (3) & $58.9 \pm 0.19$ \\
\hline S7 & 0.34 & 1.70 & 2.04 (7) & 1.12 (7) & $60.3 \pm 0.82$ \\
\hline \multicolumn{6}{|l|}{ Hills } \\
\hline H1 & 1.47 & 0.05 & 1.52 (8) & 4.76 (8) & $55.4 \pm 0.64$ \\
\hline $\mathrm{H} 2$ & 0.29 & 0.93 & $1.22(10)$ & 1.00 (13) & $62.2 \pm 1.07$ \\
\hline H3 & 0.64 & 0.05 & 0.69 (13) & 2.06 (12) & $58.3 \pm 2.04$ \\
\hline H4 & 0.98 & 0.15 & $1.13(12)$ & 3.24 (11) & $53.7 \pm 2.83$ \\
\hline H5 & 3.14 & 0.29 & 3.43 (4) & 10.12 & $53.4 \pm 2.30$ \\
\hline H6 & 3.38 & 3.58 & 6.96 (1) & 10.88 & $45.9 \pm 4.19$ \\
\hline $\mathrm{H} 7$ & 2.60 & 1.08 & 3.68 (3) & 8.47 (4) & $44.0 \pm 2.11$ \\
\hline H8 & 1.86 & 0.20 & 2.06 (6) & 6.06 (6) & $54.9 \pm 1.58$ \\
\hline H9 & 1.67 & 0.00 & 1.67 & 5.35 (7) & $57.2 \pm 1.26$ \\
\hline H10 & 2.25 & 0.15 & 2.40 & 7.29 (5) & $51.7 \pm 0.76$ \\
\hline H11 & 3.33 & 1.47 & $4.80 \quad(2)$ & $10.82(2)$ & $51.8 \pm 0.79$ \\
\hline H12 & 1.42 & 0.05 & 1.47 (9) & 4.53 (9) & $51.9 \pm 0.67$ \\
\hline H13 & 1.13 & 0.05 & 1.18 & 3.59 (10) & $47.1 \pm 2.13$ \\
\hline
\end{tabular}



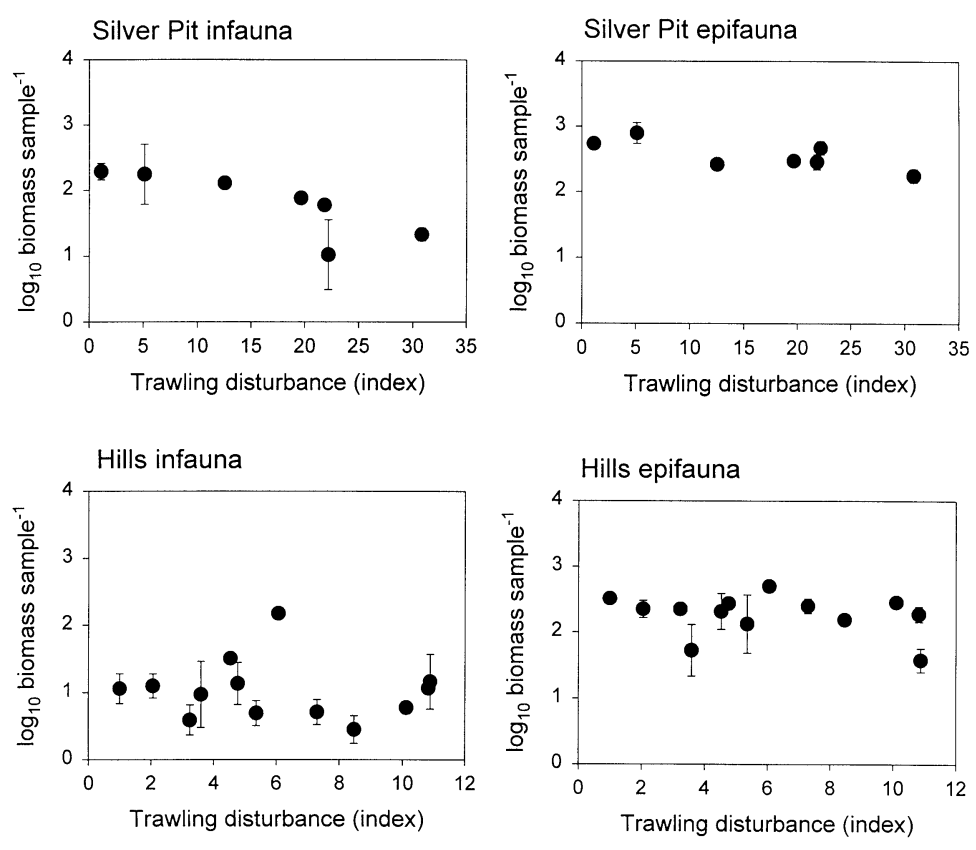

Fig. 4. Relationships between trawling disturbance and the mean biomass $( \pm \mathrm{SD})$ of infauna and epifauna in samples from the Silver Pit and Hills regions of the North Sea

and spatangoids with fishing effort (linear regression $\left.\mathrm{r}^{2}=0.78 ; F_{1,5}=17.56, \mathrm{p}=0.009\right)$ but no significant change in polychaetes $\left(F_{1,5}=0.03, \mathrm{p}=0.865\right)$. At the Hills site (Fig. 6), there was no significant change in bivalves and spatangoids with effort $\left(F_{1,11}=0.36 ; \mathrm{p}=0.560\right)$, but an increase in polychaetes $\left(\mathrm{r}^{2}=0.53 ; F_{1,11}=12.26\right.$; $p=0.005)$. Changes in the biomass of the species groups at the Silver Pit sites were reflected in significant changes in the proportions of these species (by biomass) in the community (Fig. 5). The proportion of bivalves and spatangoids decreased significantly $\left(\mathrm{r}^{2}=0.90 ; F_{1,5}=42.50 ; \mathrm{p}=0.001\right)$, while the proportion of polychaetes increased $\left(\mathrm{r}^{2}=0.68 ; F_{1,5}=10.82 ; \mathrm{p}=0.022\right)$. At the Hills sites (Fig. 6), decreases in the proportion of bivalves and spatangoids with trawling disturbance were also significant $\left(\mathrm{r}^{2}=0.39 ; F_{1,11}=7.00 ; \mathrm{p}=0.023\right)$, but increases in the proportion of polychaetes were significant only at $\mathrm{p}<0.1\left(\mathrm{r}^{2}=0.24\right.$; $\left.F_{1,11}=3.43 ; \mathrm{p}=0.090\right)$. A range of exploratory analyses confirmed that the small depth variations between sites did not account for the differences in faunal biomass and faunal composition that were observed among sites within either the Silver Pit or the Hills region. Our sampling confirmed that the community was dominated by free-living species, since they accounted for $>96 \%$ of infaunal and $>98 \%$ of epifaunal biomass at all sites.

There was no significant and positive relationship ( $p>0.1$ in all cases) between $\delta^{15} \mathrm{~N}$ and body size for infauna at any of the Silver Pit (Fig. 7) or Hills sites (Fig. 8), implying that the largest organisms in this community fed at lower trophic levels. In general, the larger organisms in samples were the bivalves and spatangoids, while the polychaetes were smaller (Table 2).

The relationships between $\delta^{15} \mathrm{~N}$ and body size for epifauna at the Silver Pit sites (Fig. 9) and Hills sites (Fig. 10) were generally positive and the relationships were well described using linear regression (Table 3). The relationships were significant at all Silver Pit sites and 10 of 13 Hills sites (Table 3). The relationships between the slopes and intercepts of these plots and levels of fishing disturbance were investigated (Fig. 11). In no cases were the slopes or intercepts significantly related to trawling disturbance (linear regression, p > 0.05), though intercepts were higher at Silver Pit sites than at Hills sites (Silver Pit: mean $\pm \mathrm{SD}=11.67 \pm 0.22$; Hills: mean $\pm \mathrm{SD}$ $=11.29 \pm 0.26$; $t$-test: $t=3.52, \mathrm{p}=0.003)$.
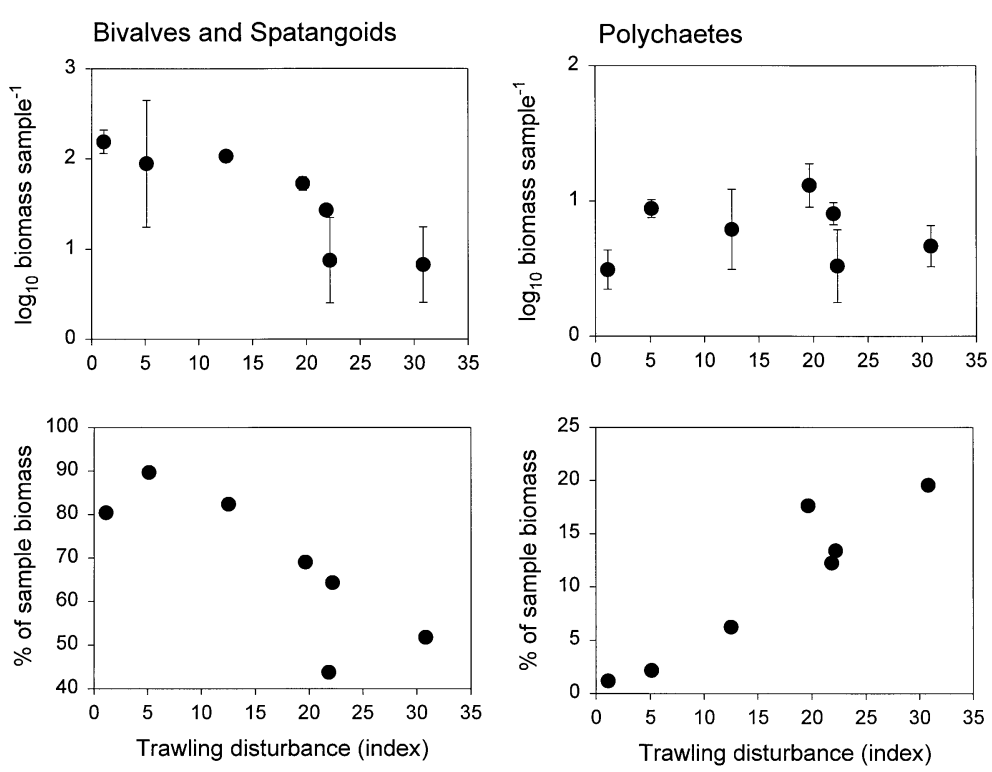

Fig. 5. Relationships between trawling disturbance and mean sample biomass $( \pm \mathrm{SD})$ of infaunal bivalves/spatangoids and polychaetes (upper panels) and between trawling disturbance and mean percentage biomass of infaunal bivalves/spatangoids and polychaetes (lower panels) in the Silver Pit region of the North Sea 
Bivalves and Spatangoids
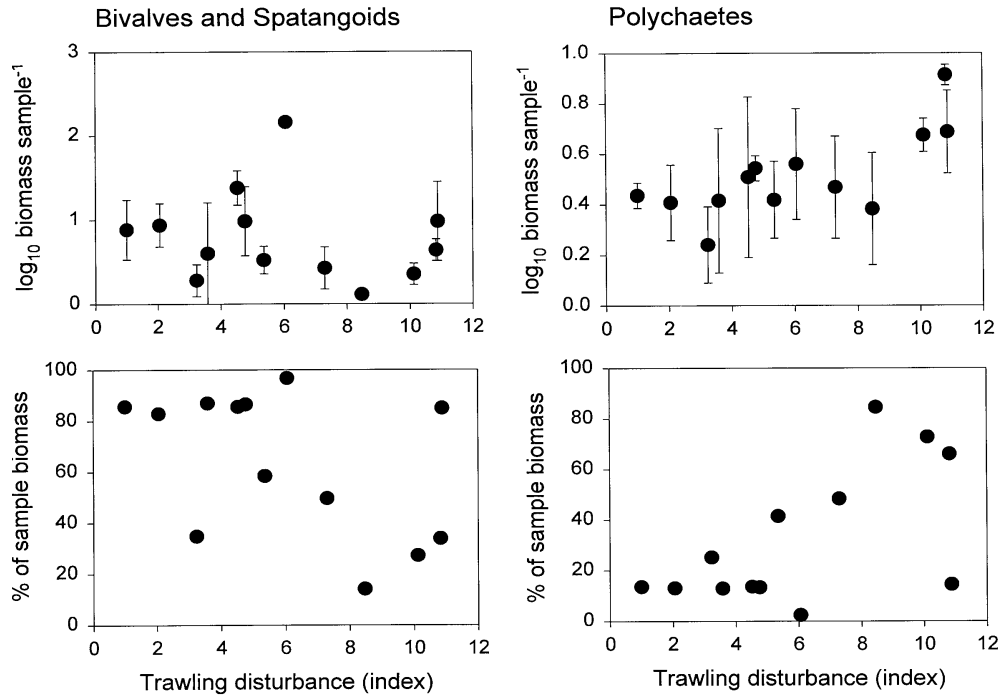

Fig. 6. Relationships between trawling disturbance and mean sample biomass $( \pm \mathrm{SD})$ of infaunal bivalves/spatangoids and polychaetes (upper panels) and between trawling disturbance and mean percentage biomass of infaunal bivalves/spatangoids and polychaetes (lower panels) in the Hills region of the North Sea

Mean $\delta^{15} \mathrm{~N}$ of the sampled infaunal and epifaunal communities were remarkably consistent across sites and were not significantly related to trawling disturbance (Fig. 12). Mean $\delta^{15} \mathrm{~N}$ was significantly higher for epifauna than infauna within the Silver Pit (infauna: mean $\delta^{15} \mathrm{~N} \pm \mathrm{SD}=9.07 \pm 0.92$; epifauna: mean $\delta^{15} \mathrm{~N} \pm \mathrm{SD}=12.27 \pm 0.19 ;$-test: $t=9.02, \mathrm{p}<$ 0.001 ) and Hills (infauna: mean $\delta^{15} \mathrm{~N} \pm \mathrm{SD}=$ $9.53 \pm 1.05$; epifauna: mean $\delta^{15} \mathrm{~N} \pm \mathrm{SD}=11.82$ \pm 0.55 ; $t$-test: $t=6.95, \mathrm{p}<0.001)$ regions.

\section{DISCUSSION}

Our results suggest that intensive trawling disturbance has led to reductions in the biomass of infauna and epifauna in the Silver Pit, and dramatic changes in the composition of the infauna. However, these changes are not reflected in the mean trophic level of the community, or the relationships between the trophic levels of different sizes of infauna. We suggest that the trophic structure of intensively fished communities has not changed, despite changes in species composition, and that this ensures the continued processing of production by those remaining invertebrates that can withstand the levels of mortality imposed by trawling.

Clearly, factors other than trawling disturbance could have explained the patterns in biomass and trophic structure that we observed. We deliberately chose to work in 2 regions where sediment type (within region) was relatively homogeneous; the relatively small varia-
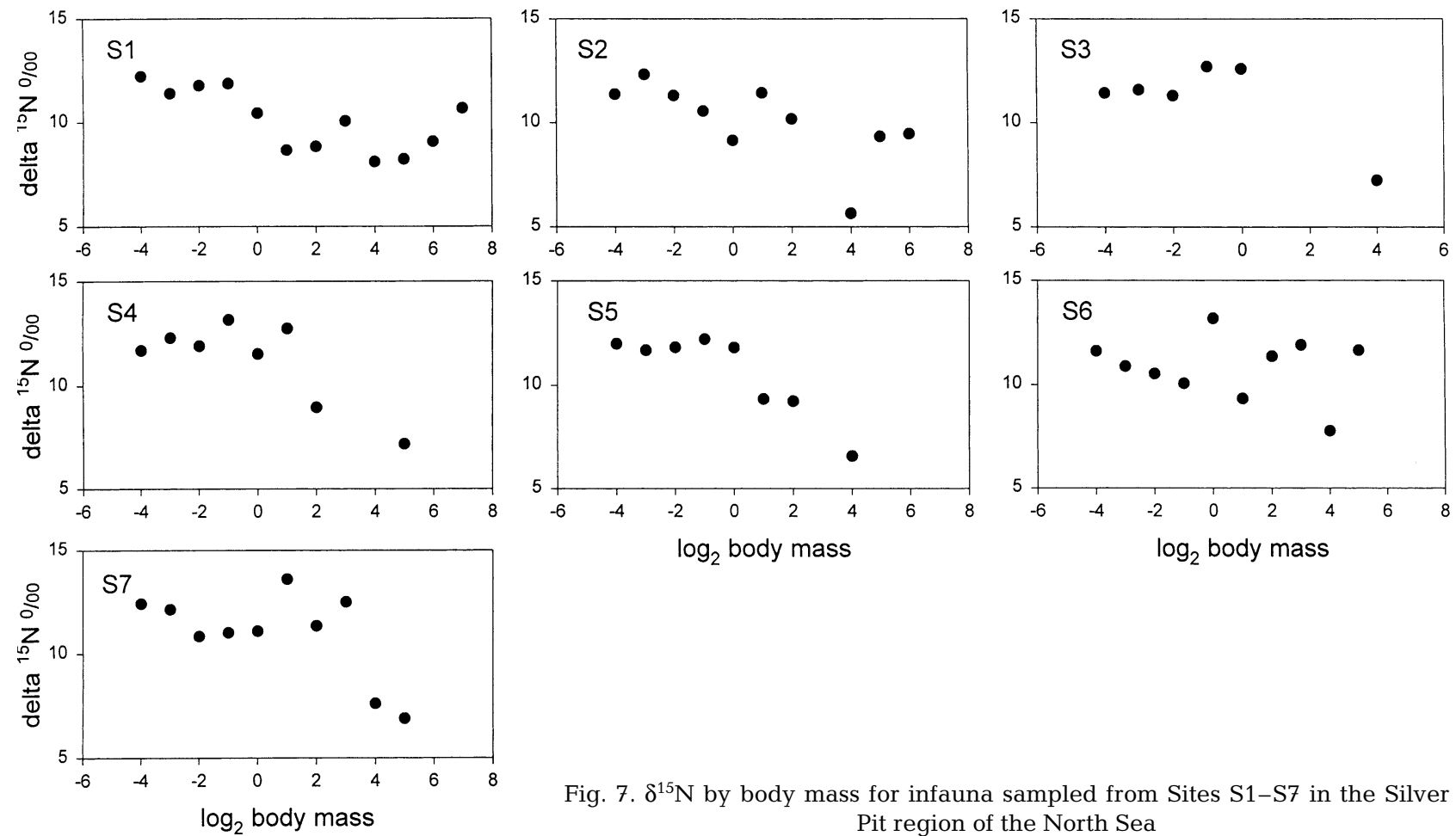

$\log _{2}$ body mass

$\log _{2}$ body mass

Fig. 7. $\delta^{15} \mathrm{~N}$ by body mass for infauna sampled from Sites S1-S7 in the Silver Pit region of the North Sea 

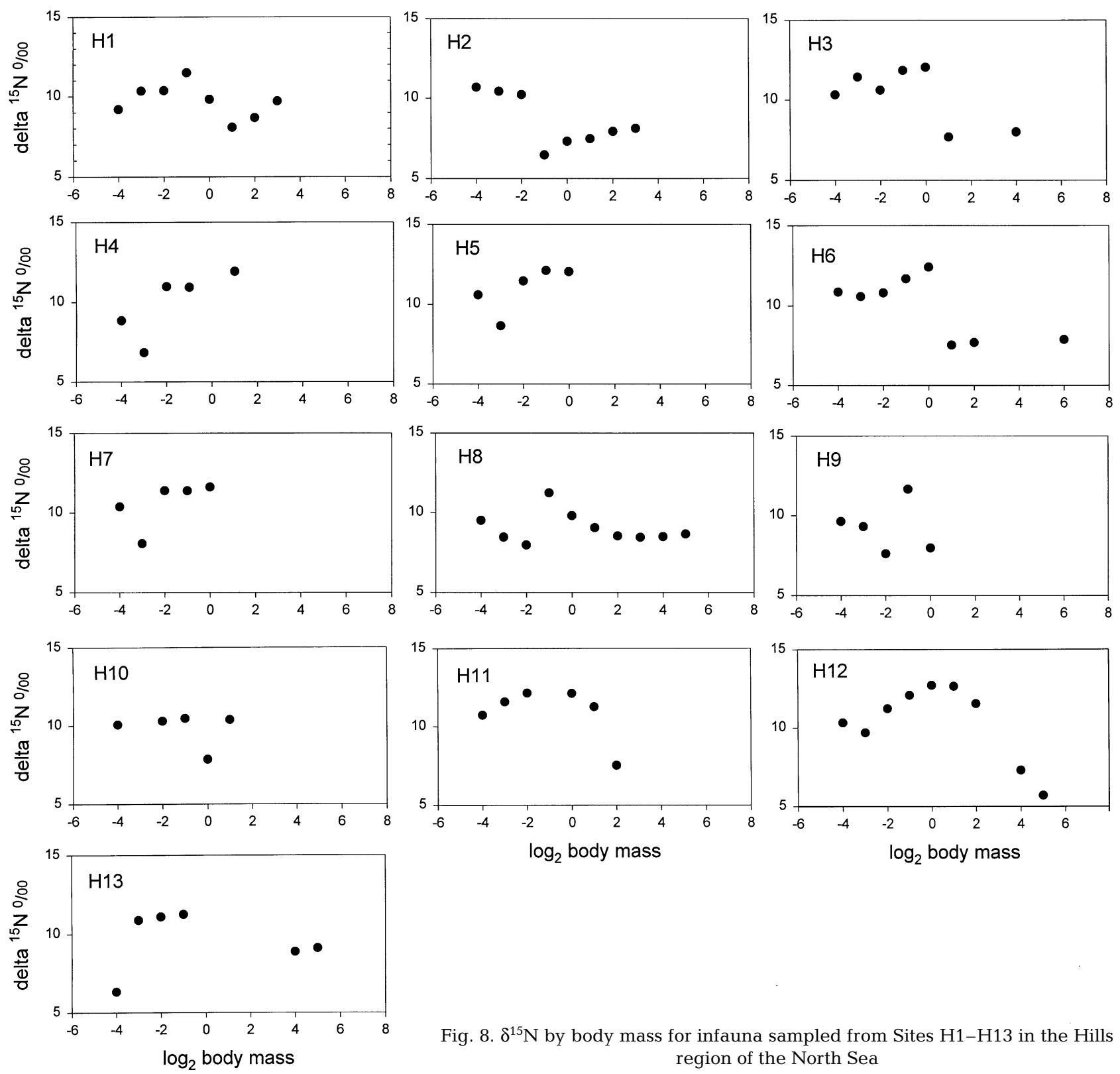

Fig. $8 . \delta^{15} \mathrm{~N}$ by body mass for infauna sampled from Sites H1-H13 in the Hills region of the North Sea

tions in mean sediment particle size reported within each region (Silver Pit: 0.02 to $0.09 \mathrm{~mm}$ diameter; Hills: 0.250 to $0.350 \mathrm{~mm}$ diameter; British Geological Survey unpubl.) would not be expected to account for the large differences in infaunal biomass among sites (e.g. Künitzer et al. 1992). Moreover, depth variations among sites within regions were modest, and did not account for observed differences in faunal biomass and faunal composition. Many other factors, such as primary production, temperature regimes and currents, determine benthic community structure, but on the scales at which we worked it is unlikely that there were large and consistent differences in these factors among sites. The ge- ographical location of sites with different fishing intensities within each grid does not follow a consistent pattern, so any gradients in community structure across each region are unlikely to confound our results. For example, in the Silver Pit (Fig. 2), the sites subject to the lowest fishing intensities (S1 and S7) are at the easternmost and westernmost extremes of the grid, with several more intensively fished sites in between. In the Hills region (Fig. 3), the most heavily fished sites are geographically close, but are mixed amongst sites subject to lower trawling intensities.

The SPUE data imply that all our study sites were fished at some time in the period 1994 to 1998. This 
Table 2. Biomass of spatangoids/bivalves and polychaetes by size class as a percentage of the total biomass of all infauna taken in anchor dredge samples from the Silver Pit and Hills regions

\begin{tabular}{|lcccc|}
\hline \multirow{2}{*}{$\begin{array}{l}\text { Size } \\
\text { class } \\
\left(\log _{2}\right)\end{array}$} & $\begin{array}{c}\text { Bivalves and } \\
\text { spatangoids }\end{array}$ & & \multicolumn{2}{c}{ Hills } \\
\hline-4 & 0.04 & 1.46 & 0.72 & 2.20 \\
-3 & 0.29 & 0.37 & 0.89 & 0.59 \\
-2 & 0.21 & 0.79 & 1.83 & 2.95 \\
-1 & 0.29 & 1.08 & 0.77 & 3.41 \\
0 & 0.37 & 0.61 & 2.92 & 2.14 \\
1 & 0.70 & 0.64 & 8.17 & 0.65 \\
2 & 1.75 & 0.35 & 19.43 & 0.93 \\
3 & 9.23 & 0.00 & 10.69 & 0.00 \\
4 & 14.31 & 0.00 & 21.66 & 0.00 \\
5 & 17.79 & 0.00 & 11.58 & 0.00 \\
6 & 14.86 & 0.00 & 7.11 & 0.00 \\
7 & 19.99 & 0.00 & - & - \\
\hline
\end{tabular}

means that we cannot infer anything about the differences between trawled and untrawled sites from this study. The use of SPUE data as an index of trawling disturbance does not give an accurate indication of the actual frequency of disturbance at the site where invertebrates were sampled. This is because the scales at which the overflight data and benthic samples can be collected are very different. Since trawling effort is very patchy, it is possible that some benthic samples were taken from unfished sites while others were taken from sites fished more frequently than SPUE suggest. Accurate knowledge of trawling history at a specific sampling site requires effort data with the highest spatial and temporal resolution. From 1 January 2000, this can be obtained through satellite tracking of larger trawlers (>24 m), although at present, it is too expensive to track all trawlers in the fleet at appropriately short time intervals. With a trawler fishing at 6 knots and a position fix every 6 min, the trawler will still have travelled over $1000 \mathrm{~m}$ between fixes.

With some assumptions we can make tentative predictions of the mean frequency of disturbance at each site. If we assume the average beam trawler tows two $12 \mathrm{~m}$ wide beams at a speed of 6 knots, then $267264 \mathrm{~m}^{2}$ of seabed, or $7.76 \%$ of the area of a $1 \mathrm{n}$ mile $^{2}$ site, will be disturbed each hour. Thus a mean sightings rate of 0.01 beam trawlers per visit corresponds to the entire area of the box being fished 6.8 times $\mathrm{yr}^{-1}$. Thus the frequency with which the entire area of the sites was trawled ranged from 0.2 to 6.5 times $\mathrm{yr}^{-1}$ in the Silver Pit and 0.2 to 2.3 times $\mathrm{yr}^{-1}$ in the Hills. These calculations assume that trawling effort is evenly distributed in the box. The estimates of trawling frequency allow us to compare these levels of disturbance with those
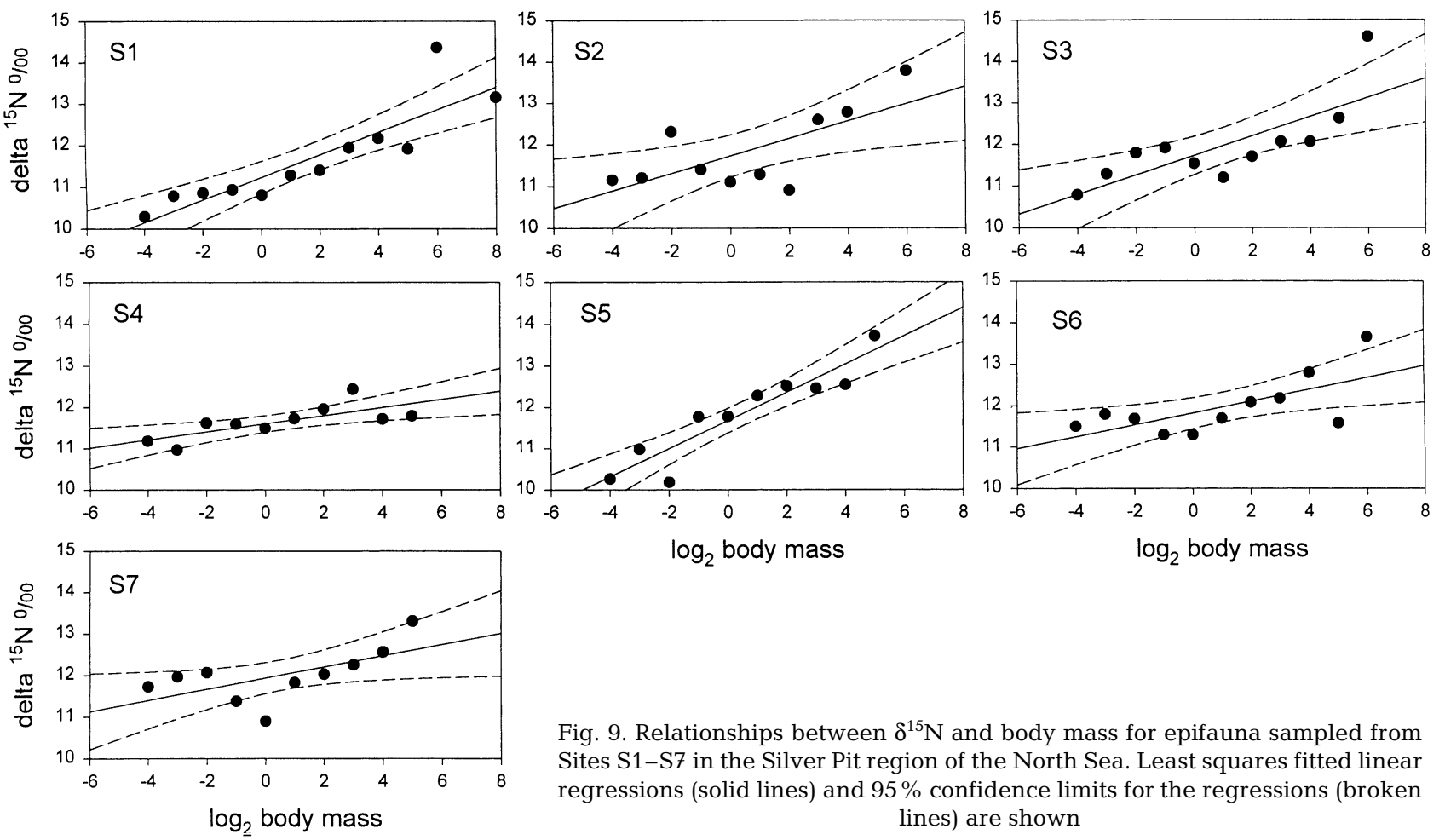

$\log _{2}$ body mass

$\log _{2}$ body mass

Fig. 9. Relationships between $\delta^{15} \mathrm{~N}$ and body mass for epifauna sampled from Sites S1-S7 in the Silver Pit region of the North Sea. Least squares fitted linear regressions (solid lines) and 95\% confidence limits for the regressions (broken lines) are shown 

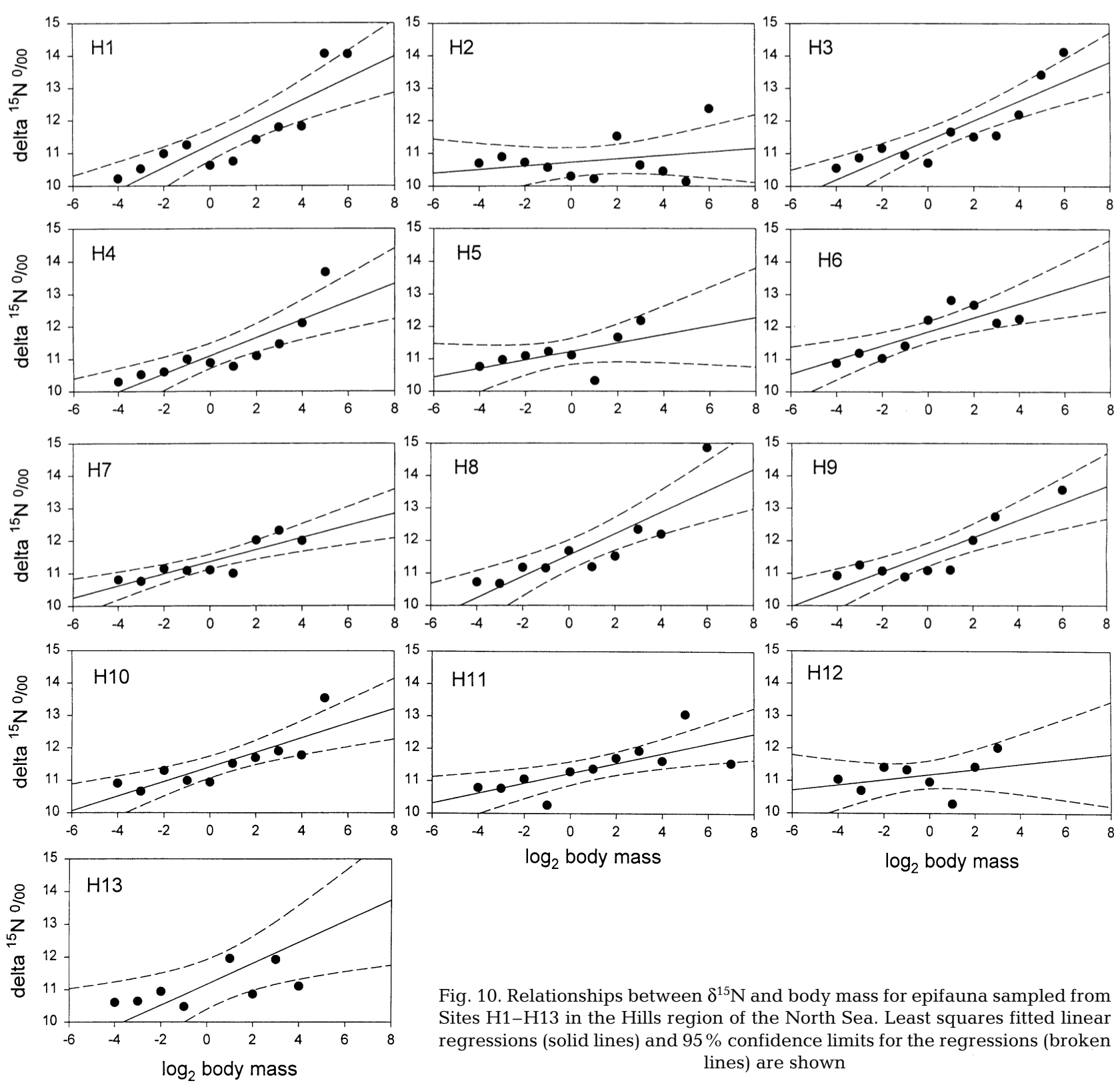

Fig. 10. Relationships between $\delta^{15} \mathrm{~N}$ and body mass for epifauna sampled from Sites H1-H13 in the Hills region of the North Sea. Least squares fitted linear regressions (solid lines) and 95\% confidence limits for the regressions (broken lines) are shown

reported in other studies. The range of trawling intensities we observed at the Silver Pit spans most of the range attributed to the Dutch beam trawl fleet in many other areas of the southern and central North Sea (Rijnsdorp et al. 1998).

Since our sampling methods estimate the abundance of infauna and epifauna on different scales, it is impossible to integrate data for infaunal and epifaunal communities. Drawing a distinction between the 2 communities is rather arbitrary, as many smaller infaunal species are likely to be eaten by larger epifauna. However, to take true quantitative samples of larger epifauna on a scale appropriate to fishing effects requires gears that integrate patchiness. Given the scarcity of many of the larger epifauna (Rumohr \& Krost 1991, Craeymeersch et al. 2000), and that any gear that would ensure equal catchability for all species could not be used to sample larger areas, we believe the benefits of sampling on a relatively large scale outweigh the disadvantages of the loss of other information. Given that beam trawlers impact swathes of seabed from $16 \mathrm{~m}$ wide (two $8 \mathrm{~m}$ beams) to $36 \mathrm{~m}$ wide (two $18 \mathrm{~m}$ beams) in these regions, we would gain little from higher replication with smaller sampling devices.

The effects of trawling on biomass and gross composition of the community were most apparent at the Silver Pit sites, where differences in trawling disturbance exceeded 30-fold and the most intensively trawled site 
Table 3. Parameters and significance of linear regressions of $\delta^{15} \mathrm{~N}$ on $\log _{2}$ body size class of epifaunal invertebrates at sites in the Silver Pit and Hills areas of the North Sea

\begin{tabular}{|llllrrr|}
\hline & Slope & Intercept & $\mathrm{r}^{2}$ & \multicolumn{1}{c}{$F$} & $\mathrm{df}$ & \multicolumn{1}{c|}{$\mathrm{p}$} \\
\hline Silver Pit & & & & & \\
S1 & 0.271 & 11.2 & 0.77 & 33.56 & 1,10 & $<0.001$ \\
S2 & 0.210 & 11.7 & 0.49 & 7.81 & 1,8 & 0.023 \\
S3 & 0.233 & 11.7 & 0.59 & 13.11 & 1,9 & 0.006 \\
S4 & 0.098 & 11.6 & 0.54 & 9.50 & 1,8 & 0.015 \\
S5 & 0.340 & 11.7 & 0.87 & 51.88 & 1,8 & $<0.001$ \\
S6 & 0.143 & 11.8 & 0.45 & 7.30 & 1,9 & 0.024 \\
S7 & 0.135 & 11.9 & 0.40 & 5.23 & 1,8 & 0.051 \\
Hills & & & & & & \\
H1 & 0.341 & 11.2 & 0.74 & 25.32 & 1,9 & $<0.001$ \\
H2 & 0.054 & 10.7 & 0.07 & 0.74 & 1,9 & 0.413 \\
H3 & 0.301 & 11.4 & 0.77 & 30.16 & 1,9 & $<0.001$ \\
H4 & 0.278 & 11.1 & 0.71 & 19.84 & 1,8 & 0.002 \\
H5 & 0.130 & 11.2 & 0.33 & 2.91 & 1,6 & 0.139 \\
H6 & 0.217 & 11.8 & 0.66 & 13.81 & 1,7 & 0.007 \\
H7 & 0.184 & 11.4 & 0.75 & 20.61 & 1,7 & $<0.001$ \\
H8 & 0.328 & 11.6 & 0.73 & 22.12 & 1,8 & $<0.001$ \\
H9 & 0.265 & 11.6 & 0.77 & 23.22 & 1,7 & $<0.001$ \\
H10 & 0.226 & 11.4 & 0.69 & 17.72 & 1,8 & 0.003 \\
H11 & 0.153 & 11.2 & 0.52 & 9.82 & 1,9 & 0.012 \\
H12 & 0.081 & 11.2 & 0.14 & 0.99 & 1,6 & 0.357 \\
H13 & 0.322 & 11.2 & 0.50 & 7.95 & 1,8 & 0.022 \\
\hline & & & & & & \\
\hline
\end{tabular}

was fished 3 times more intensively than the most intensively fished Hills site. Only the decrease in the biomass of infauna was significant in the Hills, and of smaller magnitude than in the Silver Pit. If changes in biomass are examined at those Silver Pit sites that are not fished any more intensively than the Hills sites (S1 and S7), then the effects of trawling disturbance are not apparent, so differences in trawling disturbance alone may explain the responses of the community. Moreover, it is reasonable to assume that the benthic communities in the Silver Pit region may be more vulnerable to trawling disturbance, since there are greater depths, slower tidal flows and finer sediments than in the Hills region (British Geological Survey and British Admiralty unpubl. data), suggesting a regime of lower natural disturbance. Our results, however, should not be interpreted as evidence that low levels of trawling disturbance have no effect on community structure. All the sites we considered were trawled to differing degrees, and so there may still be significant differences between all our sites and any that are unfished. Previously unfished sites are often the most vulnerable to fishing effects (Jennings \& Kaiser 1998).
The Silver Pit and Hills regions are typical of many beam trawling grounds in the southern and central North Sea. As such, the results of our studies are likely to be applicable to other beam trawling grounds in the North Sea where the fauna is dominated by free-living infauna and epifauna. Attached and sessile organisms form only a minor proportion of total biomass. The dominance of free-living species is probably a function of natural rather than trawling disturbance since, at the least intensively trawled sites, large bivalves such as Arctica islandica were still found. These bivalves are very vulnerable to trawling mortality due to their slow life histories (Witbaard \& Klein 1994). Mortalities of $20 \%$ or more have been measured for $A$. islandica in the path of a 12 m beam trawl (Lindeboom \& de Groot 1998, Bergman \& van Santbrink 2000). These rates are as high as those for many attached species. Moreover, $A$. islandica have slower growth rates, greater longevity and lower natural mortality than many habitat forming organisms, suggesting they would have lower intrinsic rates of natural increase and be more vulnerable to trawling disturbance. If trawling had been responsible for the loss of attached fauna then A. islandica would be unlikely to persist at our least frequently trawled study sites. Our results are applicable to free-living fauna of mobile substrates. It is unlikely they can be extrapolated to deeper areas with lower natural disturbance where many habitat forming species are particularly vulnerable to disturbance (Auster et al. 1996). Here, loss of habitat will have important consequences
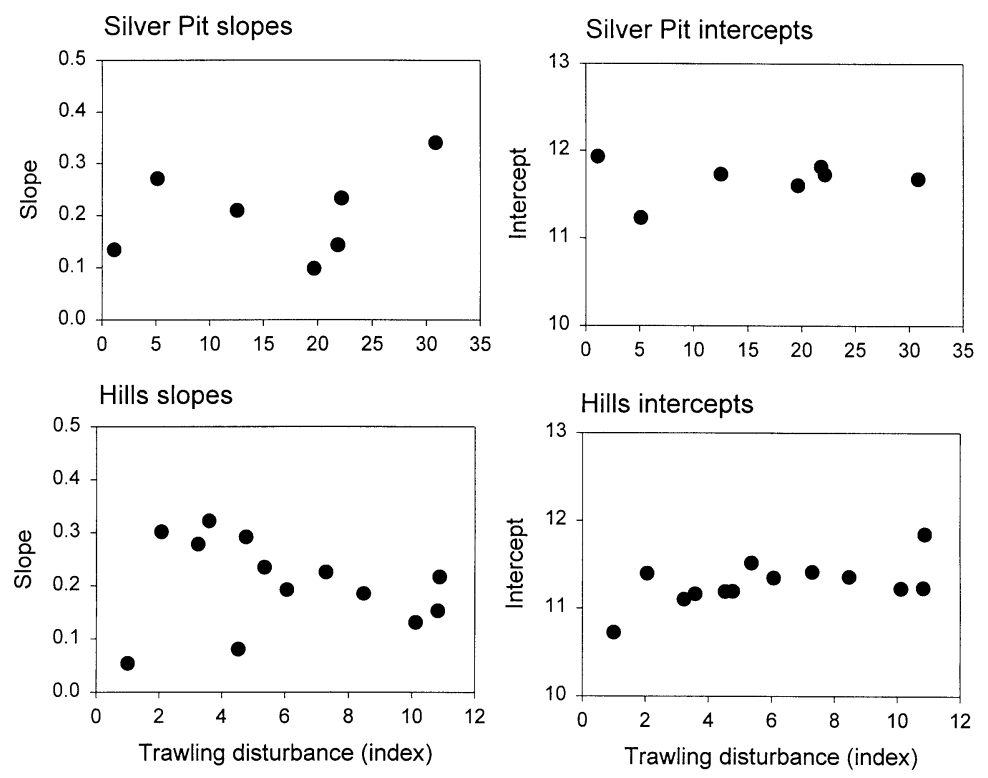

Fig. 11. Relationships between trawling disturbance and the slopes and intercepts of linear regressions fitted to relationships between $\delta^{15} \mathrm{~N}$ and body mass for epifauna samples from the Silver Pit and Hills regions of the North Sea 

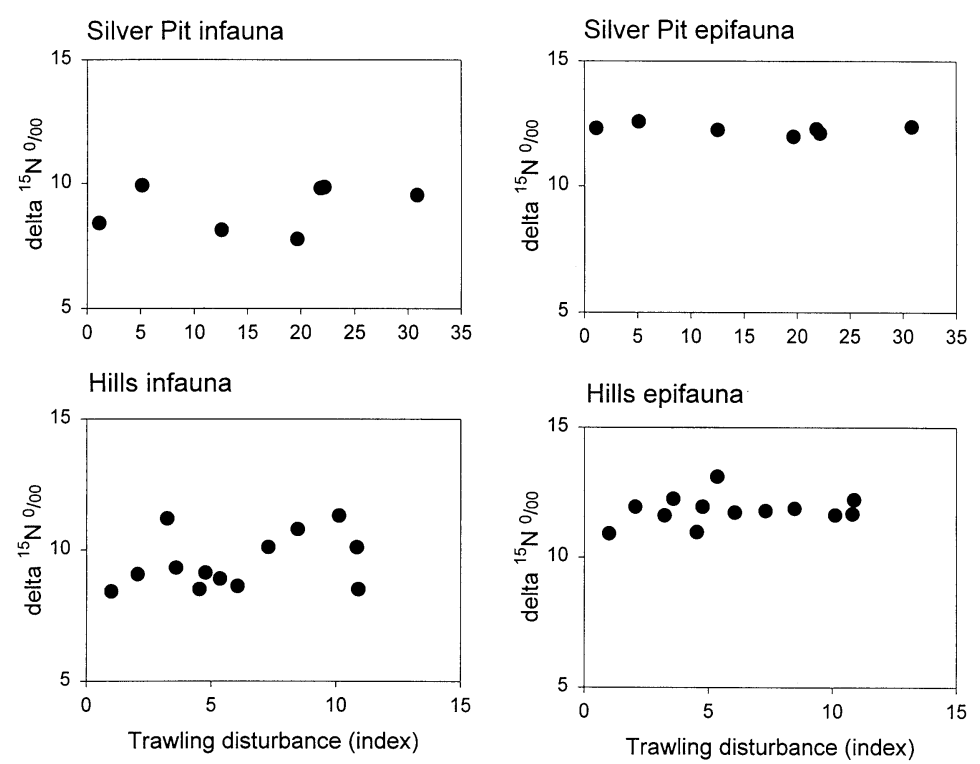

Fig. 12. Relationships between mean $\delta^{15}$ and trawling disturbance for infauna and epifauna in the Silver Pit and Hills regions of the North Sea

for many species, and stability in trophic structure is unlikely to be observed as biomass falls.

Some of the structural changes in the infauna that we observed and that appear to be related to fishing disturbance are consistent with changes that have occurred in time-series studies of infauna in specific areas of the southern and central North Sea (Kröncke 1990, 1992, Kröncke et al. 1998). Thus the proportion of small polychaetes has increased while that of bivalves and spatangoids has decreased. However, it is noticeable, that the changes in proportion of polychaetes were not strongly reflected in changes in abundance. This is interesting, since studies of long-term changes in the biomass of infauna in the southern North Sea suggest large absolute increases in polychaete biomass, but changes in community composition similar to those we observed. On this basis, the shift in community composition observed in the time-series data appears to be a fishing effect, but the increase in biomass is likely to be due to other factors as predicted by Kröncke $(1990,1992)$ and Kröncke et al. (1998). From a comparison of our spatial study with existing temporal studies, we would make the tentative suggestion that increases in biomass are less influenced by trawling disturbance that favours smaller polychaetes than by the recent increases in primary productivity of the plankton community in the southern North Sea (Reid et al. 1998a,b). Increased growth rates of plaice Pleuronectes platessa and sole Solea solea (de Veen 1976, 1978, Millner \& Whiting 1996, Rijnsdorp \& van Leeuwen 1996) could largely be a response to increases in primary production rather than the effects of beam trawl disturbance (Rijnsdorp \& van Leeuwen 1996). However, trawling disturbance will make many infaunal polychaetes more accessible to feeding fish and break open bivalves. It is well known to scientists and fishers that fish aggregate in trawl tracks to scavenge on exposed and damaged fauna (Kaiser \& Spencer 1994, Ramsay \& Kaiser 1997, Ramsay et al. 1998).

Since Minagawa \& Wada (1984) implied that nitrogen isotope abundances could provide a powerful tool for the investigation of trophic pathways, it became commonplace to assume a ${ }^{15} \mathrm{~N}$ enrichment of around 3\% for each trophic step (e.g. Cabana \& Rasmussen 1994, Vander Zanden et al. 1997, Post et al. 2000). However, as Adams \& Sterner (2000) have commented, the fractionation of $3.4 \%$ reported by Minagawa \& Wada (1984) was actually the numerical mean of reported values between 1.3 and $5.3 \%$, and this prompted many calls for experimental evaluation and validation (e.g. Gannes et al. 1997, Pinnegar \& Polunin 1999, Ponsard \& Averbuch 1999, Schoella 1999, Adams \& Sterner 2000). In the present study we avoided assigning specific trophic levels to body mass classes on the basis of their $\delta^{15} \mathrm{~N}$ and did not use a single fractionation factor and an estimate of $\delta^{15} \mathrm{~N}$ of source material to calculate absolute trophic levels. Rather, we simply assumed linearity in the relationship between $\delta^{15} \mathrm{~N}$ and trophic level.

A positive cross-species relationship between body mass and $\delta^{15} \mathrm{~N}$ is the expected consequence of larger predators eating smaller prey (Cohen et al. 1993, France et al. 1998). The relationship between body mass and $\delta^{15} \mathrm{~N}$ was significant within the epifaunal communities at most Silver Pit and Hills sites, suggesting that larger epifauna fed on smaller ones. If epifauna only preyed on other epifauna, then the gradient of the relationship between body mass and $\delta^{15} \mathrm{~N}$ would indicate the mean ratio of epifaunal predator:prey body mass. However, epifauna also prey on infauna and fish, and the gradient will be affected by these feeding interactions. The gradient of the relationship between body mass and $\delta^{15} \mathrm{~N}$ was not consistently related to the level of trawling disturbance. Rather, it appears that the trophic position of epifauna in a specific size class is more or less independent of fishing disturbance. Given that biomass fell in response to fishing disturbance across the Silver Pit sites, we suggest that patterns of energy flow in the epifaunal community are largely unaffected by the increased rates of mortality caused by trawling disturbance.

Infauna did not show an increase in $\delta^{15} \mathrm{~N}$ with body size. The infaunal community was dominated by polychaetes, bivalves and spatangoids. The polychaetes 
are generally small species with a $\log _{2}$ body mass of $<0$, while bivalves and echinoderms tend to be larger but feed at low trophic levels, as shown by the low values of $\delta^{15} \mathrm{~N}$ in large body mass categories. It would seem that 2 groups of infauna may exist, a conventional 'food chain' of polychaetes where the larger species and individuals feed on smaller ones (Schubert \& Reise 1986, Beukema 1987) and larger organisms, such as bivalves and spatangoids, that are deposit and filter feeders that feed at lower trophic levels. As such, there is little or no consumption of the smallest infauna by the largest. Polychaetes may be consumed directly by infauna and fish, while larger bivalves are only accessible if crushed by trawls or if their siphons can be nibbled by fish and epifaunal invertebrates.

Despite order of magnitude decreases in biomass of infauna, and a shift from a community dominated by bivalves and spatangoids to one dominated by polychaetes, the mean trophic level of these communities differed by less than 1 trophic level between sites and differences were not linked to levels of fishing disturbance. The lack of changes in the trophic level of the benthos could imply that the trophic structure of the community is relatively robust in the face of fishing disturbance because species less vulnerable to disturbance are taking the trophic roles of larger more vulnerable species. It would be very valuable to undertake an explicit study of whether smaller species with faster life histories begin to fill the trophic functions vacated by larger species with slower life histories because the latter cannot withstand the high mortality rates imposed by repeated trawling.

If the community is at the same trophic level, but biomass is lower, then production must increase relative to biomass if the community is to use primary production at the same rate. Alternatively, if the production to biomass ratio (P:B) does not increase, then a greater proportion of primary production will accumulate as detritus. Some modelling studies have predicted that increased accumulation of detritus may be an ecosystem response to intensive fishing (Christensen \& Pauly 1998). It is also possible that bacteria, meiofauna and other groups we did not study may play a more significant role in cycling energy when the larger epifauna and infauna are reduced, or that there is inefficient processing of energy in fished systems. The effects of fishing on energy cycling is an area that warrants much more investigation and could have implications for fish production in systems disturbed by trawling.

Acknowledgements. We wish to thank Brian Edwards, Roger Flatt, Dave Palmer, Michaela Schratzberger, Christie Stewart, Peter Walker and the officers and crew of RV 'Corystes' for their efforts in the field, and Sam Barker for running the stable isotope analyses. Thanks to the referees for constructive comments that significantly improved the text. This research was funded by the Ministry of Agriculture, Fisheries and Food, UK.

\section{LITERATURE CITED}

Adams TS, Sterner RW (2000) The effect of dietary nitrogen content on trophic level ${ }^{15} \mathrm{~N}$ enrichment. Limnol Oceanogr 45:601-607

Auster PJ, Malatesta RJ, Langton RW, Watling L, Valentine PC, Donaldson CL, Langton EW, Shepard AN, Babb IG (1996) The impacts of mobile fishing gear on seafloor habitats in the Gulf of Maine (Northwest Atlantic): implications for conservation of fish populations. Rev Fish Sci 4:185-202

Bergman MJN, Hup M (1992) Direct effects of beamtrawling on macrofauna in a sandy sediment in the southern North Sea. ICES J Mar Sci 49:5-11

Bergman MJN, van Santbrink JW (2000) Fishing mortality of populations of megafauna in sandy sediments. In: Kaiser MJ, de Groot SJ (eds) Effects of fishing on non-target species and habitats: biological, conservation and socio-economic issues. Blackwell Science, Oxford, p 49-68

Beukema JJ (1987) Influence of the predatory polychaete Nephtys hombergii on the abundance of other polychaetes. Mar Ecol Prog Ser 40:95-101

Bradshaw C, Veale LO, Hill AS, Brand AR (2000) The effects of scallop dredging on gravely seabed communities. In: Kaiser MJ, de Groot B (eds) The effects of fishing on non-target species and habitats: biological, conservation and socio-economic issues. Blackwell Science, Oxford, p 83-104

Brey T (1999) Growth performance and mortality in aquatic macrobenthic invertebrates. Adv Mar Biol 35:153-223

Brylinsky M, Gibson J, Gordon DC (1994) Impacts of flounder trawls on the intertidal habitat and community of the Minas Basin, Bay of Fundy. Can J Fish Aquat Sci 51: 650-661

Cabana G, Rasmussen JB (1994) Modelling food-chain structure and contaminant bioaccumulation using stable nitrogen isotopes. Nature 372:255-257

Cohen JE, Pimm SL, Yodzis P, Saldaña J (1993) Body sizes of animal predators and animal prey in food webs. J Anim Ecol 62:67-78

Collie JS, Escanero GA, Valentine PC (1997) Effects of bottom fishing on the benthic megafauna of Georges Bank. Mar Ecol Prog Ser 155:159-172

Collie JS, Hall SJ, Kaiser MJ, Poiner IR (2000) A quantitative analysis of fishing impacts on shelf sea benthos. J Anim Ecol 69:785-798

Christensen V, Pauly D (1998) Changes in models of aquatic ecosystems approaching carrying capacity. Ecol Appl 8: S104-S109

Craeymeersch JA, Piet GJ, Rijnsdorp AD, Buijs J (2000) Distribution of macrofauna in relation to the micro-distribution of trawling effort. In: Kaiser MJ, de Groot SJ (eds) Effects of fishing on non-target species and habitats. Blackwell Science, Oxford, p 187-197

Currie DR, Parry GD (1996) Effects of scallop dredging on a soft sediment community: a large-scale experimental study. Mar Ecol Prog Ser 134:131-150

Dayton PK, Thrush SF, Agardy MT, Hofman RJ (1995) Environmental effects of marine fishing. Aquat Conserv Mar Freshw Ecosyst 5:205-232

de Veen JF (1976) On changes in some biological parameters in the North Sea sole (Solea solea L.). J Cons Int Explor Mer 37:60-90 
de Veen JF (1978) Changes in North Sea sole stocks. Rapp PV Réun Cons Int Explor Mer 172:124-136

France R, Chandler M, Peters R (1998) Mapping trophic continua of benthic foodwebs: body size $\delta^{15} \mathrm{~N}$ relationships. Mar Ecol Prog Ser 174:301-306

Fry B, Quinones RB (1994) Biomass spectra and stable-isotope indicators of trophic level in zooplankton of the northwest Atlantic. Mar Ecol Prog Ser 112:201-204

Fry B, Sherr EB (1989) Delta 13-C measurements as indicators of carbon flow in marine and freshwater ecosystems. In: Rundel PW, Ehleringer JR, Nagy KA (eds) Stable isotopes in ecological research. Springer-Verlag, Berlin, p 196-227

Gannes LZ, OBrien DM, del Rio CM (1997) Stable isotopes in animal ecology: assumptions, caveats, and a call for more laboratory experiments. Ecology 78:1271-1276

Gilkinson K, Paulin M, Hurley S, Schwinghamer P (1998) Impacts of trawl door scouring on infaunal bivalves: results of a physical trawl door model/dense sand interaction. J Exp Mar Biol Ecol 224:291-312

Greenstreet SPR, Spence FE, Shanks AM, McMillan JA (1998) Fishing effects in northeast Atlantic shelf seas: patterns in fishing effort, diversity and community structure. III. Trends in fishing effort in the North Sea by UK registered vessels landing in Scotland. Fish Res 40:107-124

Hall SJ (1999) The effects of fishing on marine ecosystems and communities. Blackwell Science, Oxford

Heessen HJL, Daan N (1996) Long-term changes in ten nontarget North Sea fish species. ICES J Mar Sci 53: 1063-1078

Hobson KA, Welch HE (1992) Determination of trophic relationships within a high arctic marine food web using delta-C-13 and delta-N-15 analysis. Mar Ecol Prog Ser 84: 9-18

Jennings S, Kaiser MJ (1998) The effects of fishing on marine ecosystems. Adv Mar Biol 34:201-352

Jennings S, Alvsvåg J, Cotter AJ, Ehrich S, Greenstreet SPR, Jarre-Teichmann A, Mergardt N, Rijnsdorp AD, Smedstad O (1999a) Fishing effects in northeast Atlantic shelf seas: patterns in fishing effort, diversity and community structure. III. International fishing effort in the North Sea: an analysis of temporal and spatial trends. Fish Res 40: 125-134

Jennings S, Lancaster JE, Woolmer A, Cotter AJ (1999b) Distribution, diversity and abundance of epibenthic fauna in the North Sea. J Mar Biol Assoc UK 79:385-399

Jennings S, Warr KJ, Greenstreet SPR, Cotter AJ (2000) Spatial and temporal patterns in North Sea fishing effort. In: Kaiser MJ, de Groot SJ (eds) Effects of fishing on nontarget species and habitats: biological conservation and socio-economic issues. Blackwell Science, Oxford, p 3-14

Kaiser MJ (1998) Significance of bottom-fishing disturbance. Conserv Biol 12:1230-1235

Kaiser MJ, de Groot SJ (eds) (2000) The effects of fishing on non-target species and habitats: biological, conservation and socio-economic issues. Blackwell Science, Oxford

Kaiser MJ, Spencer BE (1994) Fish scavenging behaviour in recently trawled areas. Mar Ecol Prog Ser 112:41-49

Kaiser MJ, Spencer BE (1996) The effects of beam-trawl disturbance on infaunal communities in different habitats. J Anim Ecol 65:348-358

Kaiser MJ, Edwards DB, Armstrong PA, Radford K, Lough NEL, Flatt RP, Jones HD (1998) Changes in megafaunal benthic communities in different habitats after trawling disturbance. ICES J Mar Sci 55:353-361

Kaiser MJ, Ramsay K, Richardson CA, Spence FE, Brand AR (2000) Chronic fishing disturbance has changed shelf sea benthic community structure. J Anim Ecol 69:494-503
Kröncke I (1990) Macrofauna standing stock of the Dogger Bank, a comparison: 1950-1954 versus 1985-1987. ICES CM 1990/Mini 3:22

Kröncke I (1992) Macrofauna standing stock of the Dogger Bank. A comparison: III. 1950-54 versus 1985-87. A final summary. Helgol Wiss Meeresunters 46:137-169

Kröncke I, Dippner JW, Heyen H, Zeiss B (1998) Long-term changes in macrofaunal communities off Norderney (East Frisia, Germany) in relation to climate variability. Mar Ecol Prog Ser 167:25-36

Künitzer A, Basford D, Craeymeersch JA, Dewarumez JM, Dorjes J, Duineveld GCA, Eleftheriou A, Heip C, Herman P, Kingston P, Niermann U, Rachor E, Rumohr H, de Wilde PAJ (1992) The benthic infauna of the North Sea: species distribution and assemblages. ICES J Mar Sci 49:127-143

Lee AJ, Ramster JW (1981) Atlas of the seas around the British Isles. MAFF Directorate of Fisheries Research, Lowestoft

Lindeboom HJ, de Groot SJ (eds) (1998) The effects of different types of fisheries on the North Sea and Irish Sea benthic ecosystems. Netherlands Institute of Sea Research, Texel

Lindley JA, Gamble JC, Hunt HG (1995) A change in the zooplankton of the central North Sea $\left(55^{\circ}\right.$ to $\left.58^{\circ} \mathrm{N}\right)$ : a possible consequence of changes in the benthos. Mar Ecol Prog Ser 119:299-303

Mensink BP, Fischer CV, Cadée GC, Fonds M, HallersTjabbes CC, Boon JP (2000) Shell damage and mortality in the common whelk Buccinum undatum caused by beam trawl fishery. J Sea Res 43:53-64

Millner RS, Whiting CL (1996) Long-term changes in growth and population abundance of sole in the North Sea from 1940 to the present. ICES J Mar Sci 53:1185-1195

Minawaga M, Wada E (1984) Stepwise enrichment of ${ }^{15} \mathrm{~N}$ along food chains: further evidence and the relation between ${ }^{15} \mathrm{~N}$ and animal age. Geochim Cosmochim Acta 48:1135-1140

Owens NJP (1987) Natural variations in ${ }^{15} \mathrm{~N}$ in the marine environment. Adv Mar Biol 24:389-451

Pauly D, Christensen V, Dalsgaard J, Froese R, Torres F (1998) Fishing down marine food webs. Science 279: 860-863

Peterson BJ, Fry B (1987) Stable isotopes in ecosystem studies. Annu Rev Ecol Syst 18:293-320

Peterson BJ, Howarth RW, Garritt RH (1985) Multiple stable isotopes used to trace the flow of organic matter in estuarine food webs. Science 227:1361-1363

Pinnegar JK, Polunin NVC (1999) Differential factionation of $\delta^{13} \mathrm{C}$ and $\delta^{15} \mathrm{~N}$ among fish tissues: implications for the study of trophic interactions. Funct Ecol 13:225-231

Ponsard S, Averbuch P (1999) Should growing and adult animals fed on the same diet show different $\delta^{15} \mathrm{~N}$ values? Rap Comm Mass Spec 13:1305-1310

Post DM, Pace ML, Hairston NG (2000) Ecosystem size determines food-chain length in lakes. Nature 405:1047-1049

Preston T (1992) The measurement of stable isotope natural abundance variations. Plant Cell Environ 15:1091-1097

Preston T, Owens NJP (1983) Interfacing an automatic elemental analyser with an isotope ratio mass spectrometer: the potential for fully automated total nitrogen and nitrogen-15 analysis. Analyst 108:971-977

Ramsay K, Kaiser MJ (1997) Demersal fishing disturbance increases predation risks for whelks (Buccinum undatum L.). J Sea Res 39:299-304

Ramsay K, Kaiser MJ, Hughes RN (1998) Responses of benthic scavengers to fishing disturbance by towed gears in different habitats. J Exp Mar Biol Ecol 224:73-89

Reid PC, Edwards M, Hunt HG, Warner AJ (1998a) Phyto- 
plankton change in North Atlantic. Nature 391:546

Reid PC, Planque B, Edwards M (1998b) Is observed variability in the long-term results of the CPR survey a response to climate change? Fish Oceanogr 7:282-288

Rijnsdorp AD, van Leeuwen PI (1996) Changes in growth of North Sea plaice since 1950 in relation to density, eutrophication, beam-trawl effort and temperature. ICES J Mar Sci 53:1199-1213

Rijnsdorp AD, Bujis AM, Storbeck F, Visser E (1998) Microscale distribution of beam trawl effort in the southern North Sea between 1993 and 1996 in relation to the trawling frequency of the sea bed and the distribution of benthic organisms. ICES J Mar Sci 55:403-419

Rumohr H, Krost P (1991) Experimental evidence of damage to the benthos by bottom trawling with special reference to Arctica islandica. Meeresforschung 33:340-345

Schoella DA (1999) Isotope fractionation: why aren't we what we eat? J Arch Sci 26:667-673

Schubert A, Reise K (1986) Predatory effects of Nephtys hombergii on other polychaetes in tidal sediments. Mar Ecol Prog Ser 34:117-124

Editorial responsibility: Otto Kinne (Editor),

Oldendorf/Luhe, Germany
Thrush SF, Hewitt JE, Cummings VJ, Dayton PK (1995) The impact of habitat disturbance by scallop dredging on marine benthic communities: what can be predicted from the results of experiments? Mar Ecol Prog Ser 129:141-150

Thrush SF, Hewitt JE, Cumings VJ, Dayton PK, Cryer M, Turner SJ, Funnell GA, Budd RG, Milburn CJ, Wilkinson MR (1998) Disturbance of the marine benthic habitat by commercial fishing: impacts at the scale of the fishery. Ecol Appl 8:866-879

Tuck I, Hall SJ, Roberston M, Armstrong E, Basford D (1998) Effects of physical trawling disturbance in a previously unfished sheltered Scottish sea loch. Mar Ecol Prog Ser 162:227-242

Vander Zanden MJ, Cabana G, Rasmussen JB (1997) Comparing trophic position of freshwater fish calculated using stable nitrogen isotope ratios $\left(\delta^{15} \mathrm{~N}\right)$ and literature dietary data. Can J Fish Aquat Sci 54:1142-1158

Witbaard R, Klein R (1994) Long-term trends on the effects of the southern North Sea beamtrawl fishery on the bivalve mollusc Arctica islandica L. (Mollusca, bivalvia). ICES J Mar Sci 51:99-105

Submitted: August 21, 2000; Accepted: November 28, 2000 Proofs received from author(s): March 5, 2001 